\title{
PORCIONES DE FRIO ACUMULADAS EN LA REGION CENTRO DE LA PROVINCIA DE SANTA FE
}

\author{
García, M. S. ${ }^{1}$; LeVa, P. ; Tóffoli, G. ${ }^{1}$; Gariglio, n. ${ }^{2}$ \& Valtorta, S. ${ }^{1}$
}

\begin{abstract}
RESUMEN
La región centro oeste de la provincia de Santa Fe presenta inviernos benignos. Esta característica dificulta la aplicación de modelos de cuantificación de frío elaborados en regiones de climas fríos. El objetivo del presente trabajo fue cuantificar el frío invernal de dos localidades de la región centro, utilizando el modelo dinámico, aconsejado para regiones con clima cálido y subtropical. Para Sauce Viejo y Rafaela (Serie 1970-2007), se simularon las temperaturas horarias del período mayo a septiembre a través de la metodología propuesta por Parton y Logan. Con las temperaturas medias horarias, se estimaron las porciones o quantum de frío según el Modelo Dinámico. Las porciones de frío acumuladas en Rafaela y Sauce Viejo fueron de 46 y 37, respectivamente siendo la distribución a lo largo del año similar en ambas localidades.
\end{abstract}

Palabras claves: frío invernal, modelo dinámico, frutales.

\section{SUMMARY}

\section{Cold quanta accumulated in central west Santa Fe province.}

The central west region of Santa Fe province presents benign winters. This condition complicates the use of cold quantification models developed for cold climates. The objective of the present work was to quantify the winter cold for two locations in the central region, using the Dynamic Model suggested for hot and subtropical climate regions. Hourly temperatures were estimated from May to September (1970-2007) for Sauce Viejo and Rafaela, using the methodology proposed by Parton and Logan. The cold quanta were estimated according to the Dynamic Model, using mean hour temperatures. The cold quanta accumulated in Rafaela and Sauce Viejo were 46 and 37, respectively, the year distribution being similar for both locations.

Key words: winter cold, dynamic model, fruit.

1. Cátedra de Agrometeorología. Facultad de Ciencias Agrarias (UNL). Kreder 2805. (3080) Esperanza, provincia de Santa Fe. Telefax: (03496) 426400. Interno 252. e-mail: msgarcia@fca.unl.edu.ar

2. Cátedra de Cultivos Intensivos. FCA (UNL).

Manuscrito recibido el 26 de diciembre de 2012 y aceptado para su publicación el 8 de agosto de 2013. 